\title{
Shigella Outer Membrane Vesicles as Promising Targets for Vaccination
}

\author{
Muhammad Qasim ${ }^{1}$, Marius Wrage ${ }^{2}$, Björn Nüse ${ }^{2}$ and Jochen Mattner ${ }^{2, *}$ \\ 1 Department of Microbiology, Kohat University of Science and Technology, Kohat 26000, Pakistan; \\ qasim89@gmail.com \\ 2 Mikrobiologisches Institut-Klinische Mikrobiologie, Immunologie und Hygiene, Universitätsklinikum \\ Erlangen and Friedrich-Alexander Universität (FAU) Erlangen-Nürnberg, 91054 Erlangen, Germany; \\ bjoern.nuese@uk-erlangen.de (M.W.); marius.wrage@uk-erlangen.de (B.N.) \\ * Correspondence: jochen.mattner@uk-erlangen.de; Tel.: +49-913-1852-3640
}

Citation: Qasim, M.; Wrage, M.; Nüse, B.; Mattner, J. Shigella Outer Membrane Vesicles as Promising Targets for Vaccination. Int. J. Mol. Sci. 2022, 23, 994. https://doi.org/ $10.3390 /$ ijms23020994

Academic Editor: Angelo Viscido

Received: 28 December 2021

Accepted: 14 January 2022

Published: 17 January 2022

Publisher's Note: MDPI stays neutral with regard to jurisdictional claims in published maps and institutional affiliations.

Copyright: (C) 2022 by the authors. Licensee MDPI, Basel, Switzerland. This article is an open access article distributed under the terms and conditions of the Creative Commons Attribution (CC BY) license (https:// creativecommons.org/licenses/by/ $4.0 /)$.

\begin{abstract}
The clinical symptoms of shigellosis, a gastrointestinal infection caused by Shigella spp. range from watery diarrhea to fulminant dysentery. Endemic infections, particularly among children in developing countries, represent the majority of clinical cases. The situation is aggravated due to the high mortality rate of shigellosis, the rapid dissemination of multi-resistant Shigella strains and the induction of only serotype-specific immunity. Thus, infection prevention due to vaccination, encompassing as many of the circulating serotypes as possible, has become a topic of interest. However, vaccines have turned out to be ineffective so far. Outer membrane vesicles (OMVs) are promising novel targets for vaccination. OMVs are constitutively secreted by Gram-negative bacteria including Shigella during growth. They are composed of soluble luminal portions and an insoluble membrane and can contain toxins, bioactive periplasmic and cytoplasmic (lipo-) proteins, (phospho-) lipids, nucleic acids and/or lipopolysaccharides. Thus, OMVs play an important role in bacterial cellcell communication, growth, survival and pathogenesis. Furthermore, they modulate the secretion and transport of biomolecules, the stress response, antibiotic resistance and immune responses of the host. Thus, OMVs serve as novel secretion machinery. Here, we discuss the current literature and highlight the properties of OMVs as potent vaccine candidates because of their immunomodulatory, antigenic and adjuvant properties.
\end{abstract}

Keywords: outer membrane vesicles (OMVs); Shigella; vaccination

\section{Introduction}

Shigella species invade the gut-lining epithelium and cause shigellosis, also known as bacillary dysentery. Infections with Shigella are among the leading causes of bacterial diarrhea world-wide, [1] and the mortality rate of shigellosis can be high, particularly in epidemic infections with Shigella (S.) dysenteriae serotype 1 or endemic S. flexneri infections in children living in areas with a high prevalence of malnutrition [2]. Although shigellosis is a global health problem in all age groups, endemic infections in children, particularly in developing countries with poor sanitation and/or with poor personal hygiene, constitute the main disease burden [3].

Shigellae are transmitted via water, food or via the fecal-oral route. The infectious inoculum is low, which further facilitates the spread of this very contagious bacterium from one person to another. Even after diarrhea stops, an individual person can shed and transmit Shigellae for several weeks. Thus, low hygiene and sanitation standards facilitate the person-to-person spread of Shigella spp. Furthermore, therapeutic options become increasingly limited, as Shigella strains rapidly develop resistance to commonly used frontline antibiotics including beta-lactame antibiotics, fluoroquinolones, tetracyclines, and aminoglycosides, and even become multi-drug resistant (MDR) [4,5]. As there are multiple serotypes associated with illness, repeated infections in one individual are 
common. However, the decrease in the incidence of disease with increasing age suggests that protective immunity develops $[2,6,7]$. Thus, vaccination might be an adequate tool to restrain the person-to-person spread of Shigellae and/or the severity of shigellosis in any one individual.

\section{Shigella spp. and Shigellosis}

Shigella spp. are Gram-negative, non-motile, and facultative anaerobic rods belonging to the family of Enterobacteriaceae. Based on 16S rRNA sequence analyses [8,9], we know nowadays that Shigella spp. are closely related to Escherichia (E.) coli strains. Indeed, today's commensal and pathogenic E. coli and Shigella variants share common progenitor strains [10]. Thus, Shigellae are considered as E. coli strains that have acquired a specific set of genes that contribute to their specific pathogenesis and clinical pathology $[9,11]$. However, historically, Shigella spp. and E. coli strains have been classified as separate species based on their biochemical characteristics, serological typing, and clinical relevance [12-14].

The genus Shigella itself is sub-divided into four species: S. dysentriae, S. flexneri, S. boydii, and S. sonnei. Each species is composed of different serotypes based on the structure of their lipopolysaccharide (LPS) antigen, the so-called $\mathrm{O}$ antigen, repeats [15]. At least 50 different serotypes exist $[15,16]$. The identification of their distribution is pivotal for the success of vaccination strategies as acquired antibody responses to Shigellae are serotype-specific [6].

Shigellosis can present with versatile symptoms ranging from acute watery diarrhea to fulminant dysentery, accompanied by fever and abdominal cramps. While S. boydii and $S$. sonnei usually cause a relatively mild illness, which includes watery or bloody diarrhea, $S$. flexneri and $S$. dysenteriae are predominantly responsible for endemic and epidemic shigellosis in developing countries, with high transmission rates and significant fatality case rates. Particularly, S. dysenteriae serotype 1 causes severe disease and might be associated with life-threatening complications [2].

The ability of Shigella spp. to cause this wide range of symptoms has been linked to different virulence factors, which are encoded on chromosomal pathogenicity islands and the virulence plasmid [17]. These virulence factors include the type III secretion system, lipopolysaccharide (LPS) or the Shiga-toxins among others and mediate inflammation and enterotoxic effects, subvert the host cell structure and function, and suppress protective immune responses [17].

The distribution of Shigella species varies among geographical regions. S. dysenteriae is a major causative agent of severe epidemic disease in less developed areas while $S$. flexneri and S. sonnei occur primarily in developing and developed countries $[18,19]$.

Indeed, the persistent colonization of local areas by sub-lineages of $S$. flexneri may have contributed to the species' long-term success [20]. S. boydii is confined to the Indian subcontinent, and S. sonnei occurs in both transitional and developed countries $[17,18]$. Stratified analyses indicated a decrease in the prevalence of $S$. flexneri cases and an increase in the prevalence of $S$. sonnei cases concurrent with the rapid economic growth experienced by China in recent years [21], as observed in many other emerging countries [22-24]. Thus, as acquired immune responses are serotype-specific [6], the local circulating Shigella strains and serotypes need to be identified in order to develop successful vaccine candidates.

\section{Vaccination Approaches}

Several approaches have been employed to obtain effective vaccine candidates against shigellosis. These included (sub-) cellular vaccines, formalin-inactivated whole S. sonnei, glycoconjugates, subunit candidates, live attenuated deletion mutants, conjugated detoxified polysaccharide parenteral vaccines or conjugated synthetic carbohydrates among others $[6,25,26]$. Unfortunately, despite the broad variety of strategies applied and the number of potential candidates identified, there is not yet a convincing or licenced vaccine against shigellosis available. Although some vaccines have been evaluated in clinical settings, further pre-clinical and clinical studies are urgently required once the safety, im- 
munogenicity, and protection of promising vaccine candidates have been confirmed in challenge models. Owing to the wide range of Shigella serotypes and subtypes, there is a need for the development of a multivalent vaccine that represents the prevalent species and serotypes [27]. Due to their characteristic assembly of antigenic structures and virulence factors, the outer membrane vesicles (OMVs) of Shigella are promising targets for vaccination in this context. Furthermore, the possibility of mixing OMVs from multiple serotypes presumably allows the induction of a multi-serotype immunity. Last, OMV-based vaccines can be applied orally, and thus, might overcome the ineffectiveness of parenteral vaccines to stimulate a mucosal immune response.

\section{Outer Membrane Vesicles (OMVs) as Targets for Vaccination}

Outer membrane vesicles (OMVs) are approximately 50-300 nm large vesicles released by Gram-negative bacteria during growth in vivo as well as in liquid and solid culture in vitro $[28,29]$. They consist of many potential antigenic structures including proteins, lipoproteins, lipopolysaccharides (LPS), toxins, nucleic acids, lipids, and phospholipids derived from the periplasm and from the outer bacterial membrane [28,29] (Figure 1). Thus, they are promising targets for vaccination.

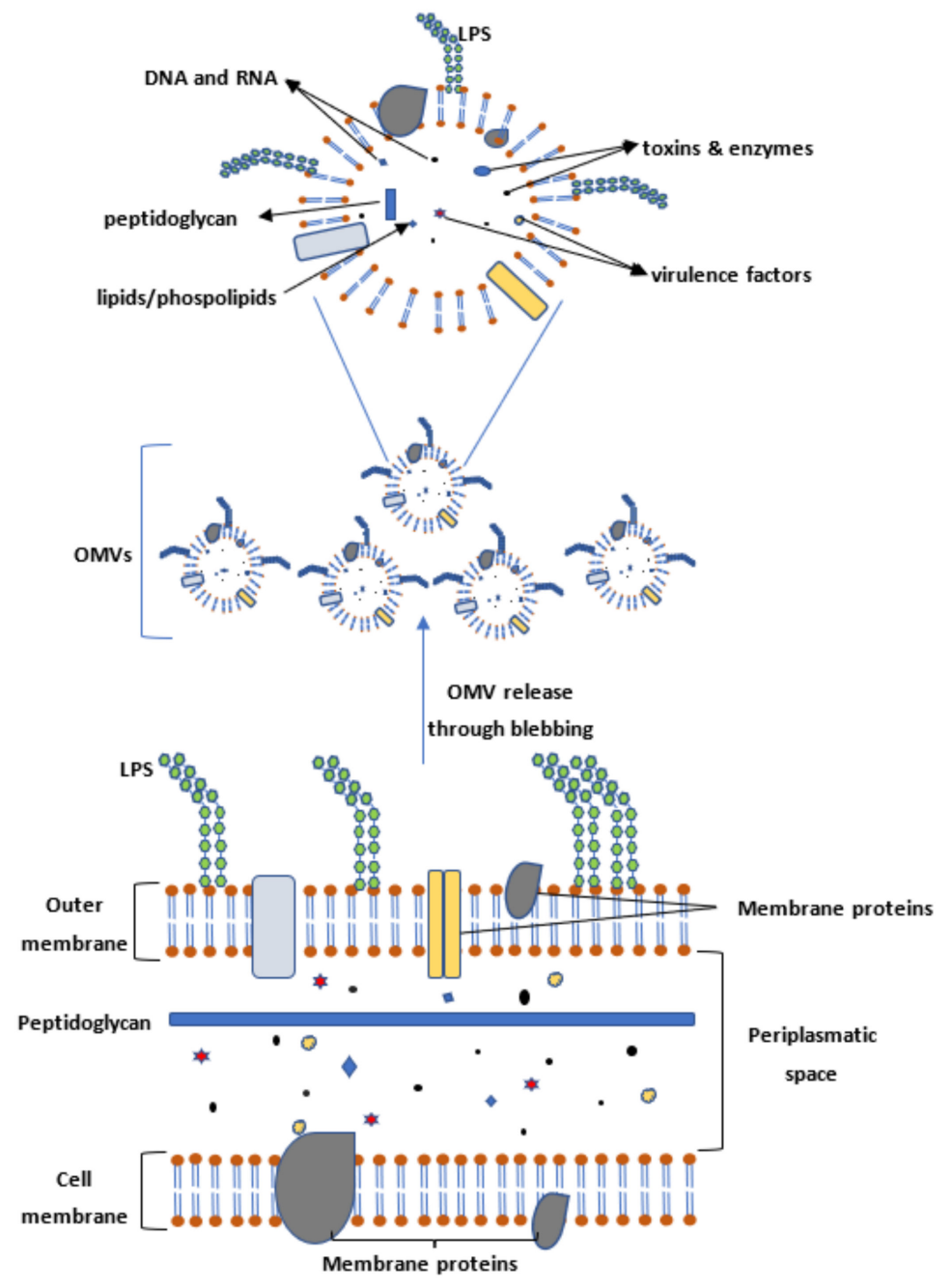

Figure 1. OMVs originate from the outer membranes of Gram-negative bacteria. They are 50-300 nm large vesicles that contain lipids, proteins, phospholipids, peptidoglycan, toxins, enzymes, LPS, DNA, and RNA derived from the periplasm between the inner membrane and the outer membrane as well as from the inner and outer membranes themselves. 
OMVs presumably contribute to the stress response of bacteria, the removal of misfolded proteins, inter-bacterial communication, the transmission of virulence factors, and the delivery of molecules and toxins [30]. Furthermore, they facilitate horizontal gene transfer, the acquisition of nutrients, and the formation of biofilms. In addition, they help in the establishment of a colonization niche, protection against antibiotics, and neutralize anti-microbial peptides $[29,31]$. Thus, OMVs improve bacterial survival on the one hand, while on the other, they also enhance immune responses in host cells, communicate with epithelial and immune cells, and modulate host-pathogen interactions, making them attractive targets for an immune attack (Figure 2).

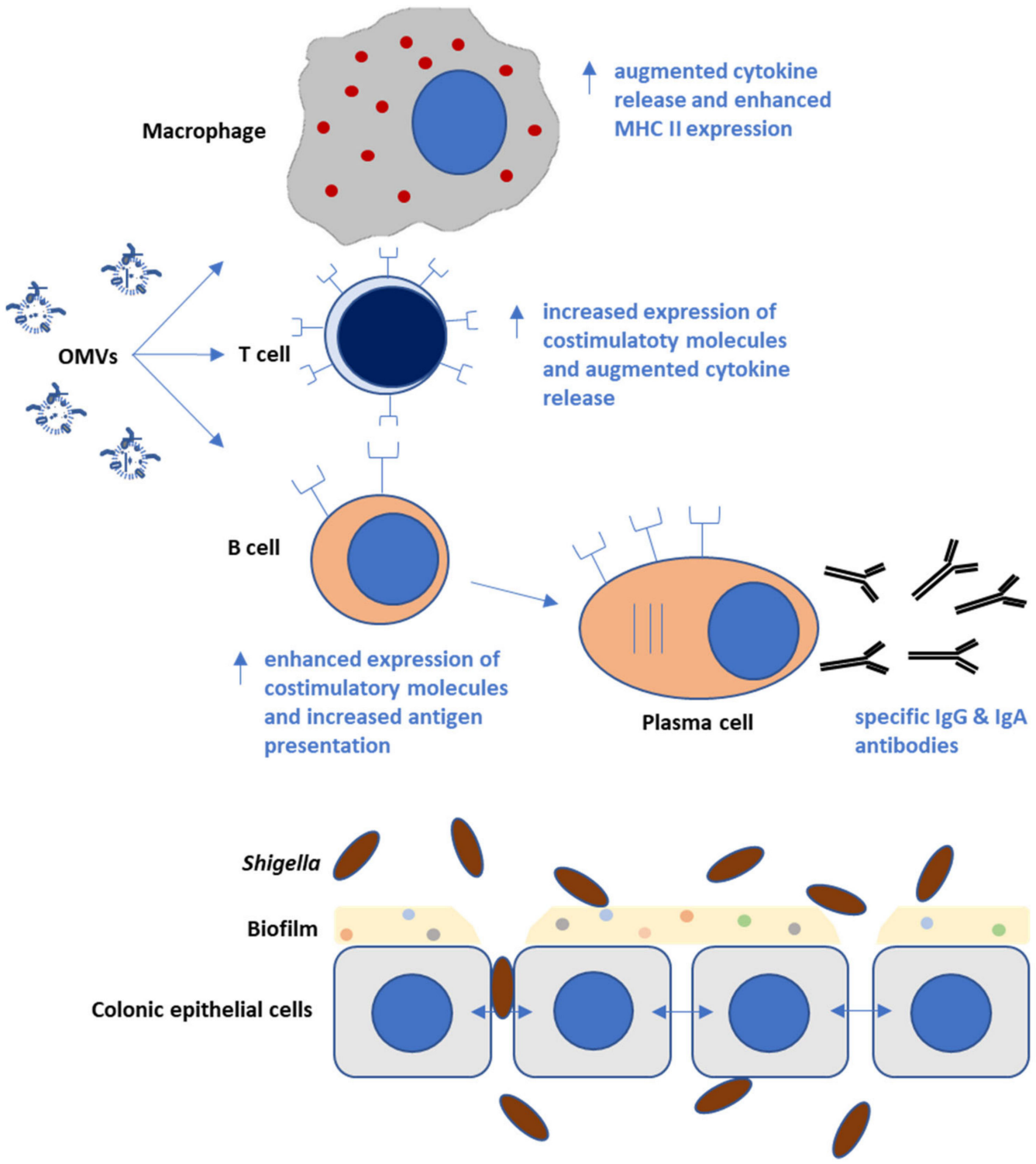

Figure 2. Shigella OMVs induce the release of different cytokines, chemokines, and specific antibodies by different immune cells, including macrophages, B and T lymphocytes. Their immune-stimulatory properties make OMVs attractive targets for vaccination against shigellosis.

Shigella OMVs contain virulence factors that facilitate the adhesion of Shigella to colonic epithelial cells, the inter- and intra-cellular spread, biofilm formation, and immune evasion. Thus, OMV-based vaccines not only ameliorate the severity of disease, but also inhibit the person-to-person spread.

Thus, OMVs represent promising tools for various biomedical applications including vaccination, immunotherapy, drug delivery and as vehicle for infection control. Indeed, 
due to their immunogenic nature, stability in various chemical and physical conditions, and low cellular toxicity, OMVs are excellent vaccine targets [32]. Thus, OMV-based vaccines against many bacteria including E. coli, Salmonella, Vibrio and Campylobacter spp., Helicobacter pylori as well as Neisseria and Shigella spp. have been intensively studied [33-37]. Although OMVs are considered as cost-effective, non-living vaccine candidates against Shigella [38], detailed knowledge about the biology of OMVs on immune-modulation and bacterial pathogenesis is missing. Thus, the objective of this review is to summarize the current knowledge on the structure and chemical composition of OMVs as well as on their biological role. Furthermore, we discuss the virulence factors of Shigellae, and in particular, of S. flexneri and their interaction with the immune system of the host. Last, we describe OMV production methods in order to obtain sufficient amounts of antigens.

\section{Immunological Responses Triggered by Shigella OMVs in Infection Models}

A number of studies have investigated the immunogenic properties of OMVs from Shigella species in animal models (Table 1).

Table 1. Evaluations of immunological response triggered by Shigella OMVs in infection models.

\begin{tabular}{|c|c|c|c|c|c|}
\hline Shigella Species & $\begin{array}{c}\text { Dose and Route of } \\
\text { OMVs }\end{array}$ & $\begin{array}{l}\text { Infection after } \\
\text { Immunization }\end{array}$ & $\begin{array}{l}\text { Duration of } \\
\text { Protection }\end{array}$ & Protection & Ref \\
\hline S. flexneri $2 \mathrm{a}$ & $20 \mu \mathrm{g}$ OMVs i.n. & 35 days & $0-15$ days & $100 \%$ & [39] \\
\hline S. flexneri 2a & $\begin{array}{l}20 \mu \mathrm{g} \text { OMVs } \\
\text { i.n./p.o. }\end{array}$ & 28 days & 0-9 days & $50 \%$ & {$[40]$} \\
\hline $\begin{array}{l}\text { S. dysenteriae } 1, \text { S. fle-neri 2a, 3a } \\
\text { and 6, S. sonnei. }\end{array}$ & $\begin{array}{l}32 \mu \mathrm{g} \mathrm{OMVs} \\
\text { p.o. }\end{array}$ & 21 days & 0-120 days & Variable & [41] \\
\hline $\begin{array}{l}\text { S. dysenteriae } 1 \Delta s t x, \text { S. flexneri } 2 \mathrm{a}, \\
\text { 3a and } 6, \text { S. boydii type } 4, \text { S. sonnei }\end{array}$ & $50 \mu \mathrm{g}$ MOMVs p.o. & & & $100 \%$ & [42] \\
\hline S. flexneri & $\begin{array}{l}\text { 20-100 } \mu \text { g OMVs i.d. } \\
\text { or p.o. }\end{array}$ & 35 days & & $20-100 \%$ & [43] \\
\hline S. flexneri 2a (N.Y-962/92) & $\begin{array}{l}3 \mu \mathrm{g} \text { recombinant } \\
\text { his-tag OmpA i.n. }\end{array}$ & 28 days & 14 days & $100 \%$ & [44] \\
\hline S. flexneri $2 \mathrm{a}$ & $1 \mu \mathrm{g}$ OmpA i.p. & 28 days & $0-14$ days & $100 \%$ & [45] \\
\hline S. flexneri 3a & $1.6-20 \mu \mathrm{g}$ OmpC s.c. & $0-21$ days & & Variable & {$[46]$} \\
\hline Genetically modified S. sonnei & $\begin{array}{c}0.2-2 \mu \mathrm{g} \\
\text { GM-MA s.c. }\end{array}$ & 0-35 days & $0-49$ days & & [47] \\
\hline S. sonnei 1790GAHB & $\begin{array}{l}\text { 29-238 } \mu \mathrm{g} \\
\text { GM-MA i.p. }\end{array}$ & 21 days & & & {$[48]$} \\
\hline S. boydii & $\begin{array}{c}25 \mu \mathrm{g} \\
\text { tolA-disrupted } \\
\text { OMVs p.o. }\end{array}$ & 54 days & & $100 \%$ & [38] \\
\hline $\begin{array}{l}\text { S. flexneri } 2 \mathrm{a} \text { and } 6 \text {, } \\
\text { S. dysenteriae } 1\end{array}$ & $\begin{array}{c}20 \mu \mathrm{g} \text { PSSP1 } \\
\text { i.n. }\end{array}$ & 28 days & 0-10 days & Variable & [49] \\
\hline
\end{tabular}

Note: ND, not determined; MOMVs: Multi-serotype outer membrane vesicles; SMOVs: Single-serotype outer membrane vesicles; GMMA: Generalized modules of membrane antigens; PSSP-1: pan-Shigella surface protein 1; NP: Nanoparticle; FA: Freund's adjuvant; Alum: aluminum hydroxide; LD50: Infectious dose 50; LD: Lethal dose MPL: Monophosphoryl lipid A; CT: cholera toxin; dmLT: double mutant (R192G/L211A) of heat-labile toxin of E.coli; i.n.: intranasal; i.p.: intraperitoneal; s.c.: subcutaneous; p.o.: per os/oral; i.d.: intradermal

In one study, an intranasal immunization with OMVs protected $100 \%$ of nine-week old, female BALB/c mice against an infection with $1 \times 10^{7}$ CFUs S. flexneri 2a 35 days later [39]. The OMVs from $S$. flexneri 2a thereby induced serotype-specific protective IgG1 and IgG2a antibodies. In another study, about $50 \%$ of OMV-immunized female BALB/c mice survived a lethal dose of $4 \times 10^{6} \mathrm{CFUs}$ of $S$. flexneri $2 \mathrm{a}$ [40]. Importantly, however, OMV vaccination 
did not only induce sero-type specific protection; for example, the oral administration of an OMV mixture from S. dysenteriae $1, S$. flexneri $2 \mathrm{a}, \mathrm{S}$. flexneri $3 \mathrm{a}, \mathrm{S}$. flexneri 6 and $S$. sonnei to 7-week female Swiss mice elicited the secretion of protective cross-reactive IgA, IgG, IgG1, IgG2a, IgG2b, IgG3, and IgM antibodies [41]. OMVs of multiple serotypes (MOMVs) including $S$. dysenteriae $1 \Delta \mathrm{stx}, S$. flexneri $2 \mathrm{a}, 3 \mathrm{a}$ and $6, S$. boydii type 4 and $S$. sonnei triggered Th1/Th2 cell-mediated immunity in BALB/c mice and provided cross-reactive protection following infection with each individual serotype [42].

Single-serotype outer membrane vesicles (SMOVs) and MOMVs of S. dysenteriae $1, S$. flexneri $2 \mathrm{a}, 3 \mathrm{a}$ and $6, S$. boydii type 4 , and $S$. sonnei induced the release of TNF- $\alpha$, IL-1 $\beta$, IFN- $\gamma$, IL-6, IL-10, and IL-4 [50]. Indeed, MOMVs induced immune responses more efficiently compared to SOMVs [50]. OMVs of S. flexneri coupled to nanoparticles (NPs) provided also protection against shigellosis in BALB/c mice. The oral and the nasal application of these NP-OMVs enhanced the release of IL-12p40 and of IL-10, and in particular, the oral vaccination protected against a lethal dose of S. flexneri [43]. Furthermore, individual components of OMVs such as OmpA enhanced the production of IFN- $\gamma$ and TNF- $\alpha$. When coupled to histaq as an adjuvant, the intranasal administration of OmpA also protected $100 \%$ of the challenged mice against shigellosis [44]. Further analyses indicated that the combination of OmpA from S. flexneri 2a with Freund's complete adjuvant also protected mice against a lethal dose of S. flexneri 2a [45]. Next to TNF- $\alpha$ and IFN- $\gamma$, OmpA also enhanced the production of IL-6 and MIP- $2 \alpha$ in this study. Furthermore, the intraperitoneal or subcutaneous application of OmpC from the S. flexneri serotype $3 a$ coupled with monophosphoryl-lipid [51] as adjuvant provided variable protection against a lethal dose of $S$. flexneri [46].

Genetic modifications of individual OMV components represent another important strategy to enhance OMV-specific immune responses. For example, the subcutaneous administration of generalized modules of membrane antigens (GMMAs) along with Freund's adjuvant (FA) or with aluminum hydroxide (alum) elicited the production of specific IgG antibodies in outbred CD1 mice [47]. A subsequent study confirmed the immunogenic potential of GMMAs in mice [48]. OMVs obtained from $S$. boydii strains with a tol-A mutation, one of the genes of the Shigella membrane, also induced the production of mucosal IgG and IgA antibodies and of inflammatory cytokines including TNF- $\alpha$, IL-6, and IFN- $\gamma$. Importantly, these OMVs also elicited $100 \%$ protection against shigellosis in neonatal Swiss mice [41]. The Pan-Shigella surface protein 1 (PSSP-1) of the S. flexneri serotypes 2a and 6 as well as of $S$. dysenteriae serotype 1 strain is known as a potent immune-modulating agent. It enhanced the production of several cytokines including IL-17A, IL-2, IL-6, IL-4, TNF- $\alpha$, and IFN- $\gamma$, and protected against shigellosis in murine infection models. Furthermore, the application of PSSP-1 along with the cholera toxin (CT) and a double mutant (R192G/L211A) of the heat-labile E.coli toxin (dmLT) triggered IgG-specific antibody responses [49].

\section{Immunoreactive Proteins in OMVs}

The outer membrane proteins (OMPs) of OMVs derived from Gram-negative bacteria induce potent immune responses. Thus, they are important targets for the development of vaccines. Indeed, several proteins obtained from Shigella OMVs have been identified and characterized. We have summarized the findings on the immune-reactive properties of some of the outer membrane proteins (Table 2) as well as on surface proteins and polysaccharides. 
Table 2. Immune-reactive proteins in OMVs from Shigella.

\begin{tabular}{|c|c|c|c|}
\hline Immune-Reactive Protein & Shigella Species & Potential Role/Function & Ref \\
\hline $\begin{array}{l}34 \mathrm{kDa} \text { major outer membrane } \\
\text { protein (MOMP) }\end{array}$ & S. flexneri $2 \mathrm{a}$ & $\begin{array}{l}\text { (i) Promotes binding to macrophages } \\
\text { (ii) Increases the production of nitric oxide } \\
\text { (iii) Enhances cytokine production }\end{array}$ & [52] \\
\hline 34 kDa MOMP & S. flexneri $2 \mathrm{a}$ & $\begin{array}{l}\text { (i) Enhances TLR2 expression on macrophages. } \\
\text { (ii) Increases the translocation of NF- } \mathrm{B} \text { to the nucleus } \\
\text { (iii) Triggers the expression of p38 MAP kinases } \\
\text { (iv) Augments the production of MyD } 88 \text { and TRAF6 } \\
\text { (v) Pormotes cytokine and chemokine production }\end{array}$ & [53] \\
\hline OmpA & S. flexneri $2 \mathrm{a}$ & $\begin{array}{l}\text { (i) Enhances the secretion of IgG and IgA } \\
\text { (ii) Activates Th1 cells \& macrophages } \\
\text { (iii) Induces the expression of MHCII, CD } 80, \text { CD } 40 \\
\text { (iv) Promotes the production of cytokines }\end{array}$ & [45] \\
\hline $34 \mathrm{kDa}$ outer membrane protein & S. flexneri $2 \mathrm{a}$ & $\begin{array}{l}\text { (i) Enhances production of nitric oxide, } \\
\text { (ii) Increases TNF- } \alpha \text { and interleukin-12 production }\end{array}$ & [54] \\
\hline Outer membrane protein A [55] & S. flexneri $2 \mathrm{a}$ & $\begin{array}{l}\text { (i) Enhances protective immunity (mucosal and systemic) by } \\
\text { protein specific IgG and IgA responses. } \\
\text { (ii) Increases the production of IgA secreting cells }\end{array}$ & [44] \\
\hline $\begin{array}{l}\text { Pan-Shigella surface protein } 1 \\
\text { (PSSP-1) }\end{array}$ & $\begin{array}{l}\text { S. flexneri } 2 \mathrm{a} \text { and } 6 ; 5 . \\
\text { dysenteriae } 1\end{array}$ & $\begin{array}{l}\text { (i) Enhances local and systemic antibody responses } \\
\text { (ii) Increases the production of interleukin } 17 \mathrm{~A} \text { and } \\
\text { gamma interferon. }\end{array}$ & [49] \\
\hline 38-kDa OmpC & S. flexneri $3 a$ & Increases B-cell specific antigenic epitopes (based on modelling) & [46] \\
\hline Outer membrane protein A [55] & S. flexneri $2 \mathrm{a}$ & $\begin{array}{l}\text { (i) Enhances the production of IgG and IgA } \\
\text { (ii) Induces IL- } 6 \text { and IL-10 production } \\
\text { (iii) Increases MHC II and CD } 86 \text { expression on B cells } \\
\text { (iv) Promotes the differentiation of B cells into antibody } \\
\text { secreting plasma cells }\end{array}$ & [56] \\
\hline Outer membrane protein A [55] & S. flexneri $2 \mathrm{a}$ & $\begin{array}{l}\text { (i) Activates NF- } \kappa \mathrm{B} \\
\text { (ii) Enhances the production of cytokines and of NO } \\
\text { (iii) Stimulates the T cells to release IFN- } \gamma \text { and IL-2 }\end{array}$ & [57] \\
\hline EpiMix $^{\circledR}$ & S. flexneri & $\begin{array}{l}\text { (i) Increases the secretion of specific serum IgG } \\
\text { (ii) Enhances IgA, IL- } 4 \text {, IL-2and IFN- } \gamma \text { levels in feces }\end{array}$ & [58] \\
\hline
\end{tabular}

A $34 \mathrm{kDa}$ major outer membrane protein (MOMP) of the $S$. flexneri serotype 2a enhances bacterial attachment to macrophages. It also augments the production and the release of nitric oxide and of various cytokines and chemokines including granulocyte-colony stimulating factor (G-CSF), IL-12p70, TNF- $\alpha$, IL-6, MIP-1 $\alpha$, MIP-1 $\beta$, and RANTES [52,53]. Furthermore, the $34 \mathrm{kDa}$ MOMP promotes the expression of the Toll-like receptor (TLR2) as well as of MHC class II and CD80 molecules on macrophages, and thus, increases their stimulatory capacity. MOMP also activates $\mathrm{p} 38 \mathrm{MAP}$ kinase signaling and promotes the translocation of NF- $\mathrm{KB}$ to the nucleus, affecting the transcription and expression of other genes [53]. Similarly, the $24 \mathrm{kDa}$ and $57 \mathrm{kDa}$ MOMPs of S. flexneri also enhance the production of nitric oxide, TNF- $\alpha$, and IL-12 in mouse macrophages, and thus, promote Th1 responses [54,59].

OmpA plays a pivotal role in the pathogenesis of Shigellae as described above. Furthermore, OmpA is highly immunoreactive. Thus, OmpA increases the secretion of IgG and IgA, and induces Th1 cells in mice. OmpA also activates macrophages and B cells, and enhances the expression of MHC class II, CD80, and CD40 molecules on both cell subsets. Furthermore, it augments the production of Th1 cytokines. Importantly, OmpA protects mice against a lethal dose of S. flexneri [44]. Similar as described for the $34 \mathrm{kDA}$ MOMP, TLR2 engagement mainly mediates these immunological effects of OmpA [45]. In 
contrast to the $34 \mathrm{kDA}$ MOMP, OmpA engages protein tyrosine kinase, ERK, and NF- $\mathrm{B}$ as signaling pathways [56].

Human umbilical cord sera react to OmpC, a 38-kDa outer membrane protein of the $S$. flexneri serotype $3 \mathrm{a}$. This reactivity has been associated with protective activity [46].

Interestingly, the Omps of one Shigella species can elicit cross-reactive immune responses against other Shigella species, as shown, for example, for OmpA and OmpC of $S$. dysentariae serotype 1 [60]. However, Omps do not only provide cross-species protection, but can also elicit immune responses across genera. Thus, the recombinant LacVax ${ }^{\circledR}$ OmpA of Lactococcus lactis (L. lactis) induced antibody- and immune cell-mediated protection against Shigella infections [61].

EpiMix $^{\circledR}$, the chemically synthesized conserved epitopes of OmpA and of OmpC of $S$. flexneri, exhibit epitope-specific antibody responses following intramuscular administration in mice. Specifically, EpiMix ${ }^{\circledR}$ stimulated the secretion of specific IgA and IgG antibodies in the blood, and the release of IL-4, IL-2, and IFN- $\gamma$ in the feces [58].

Pan-Shigella surface protein 1 (PSSP-1), a conserved Shigella protein, also provides immunological protection against various Shigella species including $S$. flexneri serotypes 2a, 5a, and 6 as well as against $S$. boydii, S. sonnei, and S. dysenteriae serotype 1 . Specifically, PSSP-1 induces local and systemic antibody responses as well as the production of IL-17A and IFN- $\gamma$ [49].

Furthermore, polysaccharides might be interesting targets for vaccination as they are often the main components of the outer cell wall in various Gram-negative bacteria. Indeed, the mucosal delivery of polysaccharide antigens via OMVs induced protection against S. flexneri infection in mice [43]. The LPS of Shigella flexneri is a hexa-acylated isoform that can trigger optimal inflammatory activity. However, Shigellae drastically change the degree of acylation of the lipid A component of LPS during invasion into the host cell. The purified hypo-acylated LPS exhibits a reduced inflammatory potential, which allows the bacteria to lower the sensory activity of the immune system and to escape the downstream anti-bacterial effector mechanisms [62]. Serum IgG antibodies against LPS antigens also correlate with effective protection against shigellosis [63]. This is the reason why LPS or parts of LPS are utilized as components in conjugate compounds [64].

However, the structure of LPS, especially the $\mathrm{O}$ antigen, is diverse between individual Shigella serovars. Thus, the cross-reactivity of existing antibodies is likely to be limited. However, LPS from locally endemic circulating strains can trigger cross-reactivity in sera of patients infected with non-local Shigella spp. (unpublished observations). Interestingly, the O-specific polysaccharides with their preserved heptosis or Kdo residuals presumably preserve cross-reactivity to other Shigella spp. [65].

\section{Virulence Factors of Shigella OMVs}

Shigella species, like other Gram-negative bacteria, secrete OMVs during growth in vitro and in vivo. OMVs help to establish bacterial pathogenesis. They also deliver virulence factors including toxins into host cells [30]. We have summarized several virulence factors and toxins that Shigella spp. release in Table 3. 
Table 3. Virulence factors of Shigella OMVs.

\begin{tabular}{|c|c|c|c|}
\hline Shigella Species & Virulence Factors & Putative Function(s) & Ref \\
\hline \multirow{14}{*}{ S. flexneri } & $\begin{array}{l}\text { MxiD, an outer membrane protein } \\
\text { (omp) }\end{array}$ & $\begin{array}{l}\text { Secretion of the Ipa invasins (IpaA, IpaB, and } \\
\text { IpaC, ) of S. flexneri. MxiD is an essential } \\
\text { component of the Ipa secretion apparatus. }\end{array}$ & {$[66]$} \\
\hline & Outer membrane proteinA [55] & $\begin{array}{l}\text { IcsA exposition, cell-to-cell-spread and } \\
\text { protrusion formation }\end{array}$ & [67] \\
\hline & SopA, outer mem-brane protease & $\begin{array}{l}\text { Required for the polar localization of IcsA and } \\
\text { the actin-based motility inside infected cells }\end{array}$ & [68] \\
\hline & Outer membrane protein IcsA (VirG) & $\begin{array}{l}\text { Promotes bacterial transmission from host cell to } \\
\text { host cell, mediates actin filament nucleation and } \\
\text { unidirectional actin-based motility of Shigellae }\end{array}$ & [69] \\
\hline & Outer membrane protein IcsA (VirG) & $\begin{array}{l}\text { Involved in the actin-based motility required for } \\
\text { intra- and intercellular Shigella spread }\end{array}$ & {$[70]$} \\
\hline & Outer membrane protein IcsA (VirG) & $\begin{array}{l}\text { Intracellular and cell-to-cell spread through } \\
\text { polymerization of actin. Phosphoryation of IcsA } \\
\text { and subsequent modulation of LcsA function }\end{array}$ & {$[71]$} \\
\hline & Outer membrane protein IcsA (VirG) & $\begin{array}{l}\text { Responsible for biofilm formation and bacterial } \\
\text { cell to cell contact }\end{array}$ & [72] \\
\hline & Outer Membrane Lipoprotein, MxiM & $\begin{array}{l}\text { Plays a role in Shigella invasion and in the type } \\
\text { III secretion system }\end{array}$ & [73] \\
\hline & Outer Membrane Lipoprotein, MxiM & $\begin{array}{l}\text { Supports the stability and localization of MxiD, } \\
\text { it is required for the assembly in cells }\end{array}$ & [74] \\
\hline & MxiJ, a lipoprotein & $\begin{array}{l}\text { Mediates the secretion of Shigella Ipa invasins } \\
\text { (IpaA, IpaB, and IpaC) }\end{array}$ & [75] \\
\hline & Outer membrane protein $C(\mathrm{ompC})$ & $\begin{array}{l}\text { Involved in the spread of Shigella in epithelial } \\
\text { cells }\end{array}$ & [76] \\
\hline & YaeT (Omp85) & $\begin{array}{l}\text { Required for the secretion and expression of } \\
\text { Shigella auto-transporters IcsA and SepA. }\end{array}$ & [77] \\
\hline & $\begin{array}{c}\text { Cardiolipin } \\
\text { (Gene encoded on synthase ClsA) }\end{array}$ & $\begin{array}{l}\text { Involved in the surface localization of IcsA and } \\
\text { spread of Shigella }\end{array}$ & [78] \\
\hline & $\begin{array}{l}\text { Outer membrane phospholipase A } \\
\text { (OMPLA)-PldA }\end{array}$ & $\begin{array}{l}\text { Essential for membrane stability and integrity, } \\
\text { and type III secretion }\end{array}$ & [79] \\
\hline $\begin{array}{l}\text { S. dys-enteriae, } \\
\text { S. flexneri }\end{array}$ & Outer membrane protease IcsP & $\begin{array}{l}\text { Modulates the quantity and distribution of IcsA; } \\
\text { role in actin-based motility-based Shigella spread }\end{array}$ & {$[68,80-84]$} \\
\hline
\end{tabular}

In detail, MxiD, a $64 \mathrm{KDa}$ outer membrane protein (membrane-associated ring-forming protein, MxiD), for example, perpetuates the secretion of the Ipa invasins (IpaA, IpaB, and $\mathrm{IpaC}$ ) of S. flexneri, which are pivotal for bacterial invasion into epithelial cells of the host [66]. MxiD is also an important component of the needle complex of the type III secretory machine of Shigellae $[74,85]$.

Furthermore, the outer membrane lipoprotein, MxiM, plays a pivotal role in the invasion of Shigellae. Similar to MxiD, MxiM also acts though the type III secretion system [74,76]. MxiM also stabilizes MxiD in its location and both MxiD and MxiM contribute to the assembly of the type III secretion system machinery and the needle complex [74]. Another lipoprotein, MxiJ, plays a key role in the invasion process due to the secretion of the Ipa invasins, IpaA, IpaB, and IpaC of Shigellae [75].

A $35 \mathrm{KDa}$ outer membrane protein A [55] is involved in IcsA exposition, cell-to-cellspread, and protrusion formation [67]. OmpA plays also a vital role in other aspects of bacterial pathogenesis such as biofilm formation, host cell invasion, intracellular spread, the evasion of immune defences, and the mediation of cytokine production. In addition, it 
modifies host cell survival and mitochondrial fragmentation. Furthermore, OmpA serves as a receptor for bacteriophages [86-89].

The outer membrane protein IcsA (VirG) is an adhesin-like autotransporter protein of Shigella that is regulated by the type III secretion system. It is required for the pathogenesis of Shigella [90]. IcsA promotes the polymerization of actin. Thus, it is involved in the actin-mediated intra- and intercellular transmission of Shigella spp. in the host [69-71]. Furthermore, IcsA mediates biofilm formation and bacterial cell-cell communication [72].

SopA, the outer membrane protease of Shigella, is required for the polar localization of IcsA and the actin-based motility inside infected cells [68]. SopA, along with other effector proteins of the pathogenicity islands of Shigella is also responsible for the invasion of epithelial cells [91] and the induction of diarrhea [92].

YaeT (Omp85) is required for the secretion and the expression of the autotransporters IcsA and SepA of S. flexneri [77]. It acts as a Stx phage recognition site, mediates the dissemination of Shiga toxins, and the insertion of proteins in the outer membranes of Enterobacteriaceae [93-95].

The outer membrane protease (IcsP) cleaves the IcsA protein, and thus, controls the quantity and the distribution of IcsA. It also has an important role in the actin-based spread of Shigella in host tissues [68,80-84].

Cardiolipins are acidic diphosphatidylglycerols encoded by the synthase ClsA. They are involved in the surface localization of IcsA and the spread of Shigella [78]. Cardiolipins also promote the transportation of LPS to the outer membrane in Gram-negative bacteria [96].

Furthermore, the outer membrane phospholipase A (OMPLA), PldA and the $\beta$-barrel proteins in the outer membrane are responsible for the structural stability of Shigella membranes and type III secretion [79,97].

Thus, in summary, multiple virulence factors of Shigella spp. accumulate in OMVs. Thus, OMVs are presumably even more immunogenic compared to whole bacteria themselves.

\section{Methods for Enhancing Shigella OMV Release and Yield}

Bacteria produce OMVs during growth or infection in vitro and in vivo. The main hurdle in the isolation of OMVs is their low yield, as bacteria release only small quantities of OMVs. To tackle this problem, different approaches to increase the production and release of OMVs have been described. These include genetic manipulation, nutrient depletion [36,37,48,98-102], oxidative stress [103], heat shock exposure [104,105] or induction by detergents [106,107], antibiotics [108-110], peptides [31,111] or sonication [112-114]. Although these approaches are effective and enhance the induction and release of OMVs, they influence the size and the chemical composition of OMVs, and subsequently, the cellular interaction and immune response $[31,105,107,110,112,115-120]$.

With respect to genetic manipulations, the release of OMVs in S. boydii serotype 4 strains was enhanced by about $60 \%$ due to a disruption of the tolA gene in the outer membrane. The released OMVs stimulated the secretion of mucosal IgG and IgA and of TNF- $\alpha$, IL-6, and IFN- $\gamma$ in immunized mice [38]. Disruption of the Tol-Pal system in S. flexneri $\Delta$ tolR mutants even resulted in an 8-times increase in the release of OMVs. The produced OMVs still induced specific antibodies and the expression of MHC-II or CD40 [121].

The evolution of generalized modules for membrane antigens (GMMA) due to the deletion of the tolR gene has been utilized to increase the release of OMVs in S. sonnei. GMMA are strongly immunogenic, but less toxic; thus, they appear to be suitable for use in human trials [48]. Another study also showed that mutations in tolR and galU enhanced the production of GMMA [47]. Mutations in the virK gene of S. flexneri also increased the production of OMVs in a temperature-dependent manner [122]. 


\section{Augmenting OMV Immune-Reactivity}

To utilize OMVs as targets for vaccination, their immunological properties can be enhanced due to the application of different methods (Table 4).

Table 4. Methods for enhancing the release, the immunological efficiency and the safety of Shigella OMVs.

\begin{tabular}{|c|c|c|c|c|}
\hline Method & Mechanism & Increase in OMV Release & Immunological Efficiency & Ref \\
\hline \multirow[t]{5}{*}{$\begin{array}{l}\text { Enhancing OMV } \\
\text { release }\end{array}$} & $\begin{array}{c}\text { Disruption of tolA, one of } \\
\text { the genes of the Tol-Pal } \\
\text { system of membrane }\end{array}$ & $60 \%$ & $\begin{array}{l}\text { Mucosal IgG and IgA, } \\
\text { pro-inflammatory cytokines } \\
(\mathrm{TNF}-\alpha, \mathrm{IL}-6, \mathrm{IFN}-\gamma)\end{array}$ & [38] \\
\hline & $\begin{array}{c}\text { Distruption in Tol-Pal } \\
\text { system in outer membrane }\end{array}$ & More than 8-times & $\begin{array}{l}\text { Enhanced production of } \\
\text { anti-bodies and expression of } \\
\text { MHC II and costimulatory } \\
\text { molecules }\end{array}$ & [121] \\
\hline & $\begin{array}{l}\text { Development of GMMA by } \\
\text { deletion of tolR }\end{array}$ & Economic and high yield & Highly immunogenic & [48] \\
\hline & $\begin{array}{l}\text { Null mutants of tolR } \\
\text { and gall }\end{array}$ & $\begin{array}{l}\text { High yield, increased } \\
\text { production of GMMA }\end{array}$ & Highly immunogenic & {$[47]$} \\
\hline & virK mutant enhance the & $\begin{array}{l}\text { High yield, OMV over- } \\
\text { production }\end{array}$ & ND & [122] \\
\hline \multirow[t]{5}{*}{ Enhancing efficiency } & $\begin{array}{l}\text { Mixing of OMVs from } \\
\text { multiple Shigella species to } \\
\text { obtain MOMVs }\end{array}$ & ND & $\begin{array}{l}\text { Consistent broad spectrum } \\
\text { antibody response and } \\
\text { protection against all tested } \\
\text { serotypes }\end{array}$ & {$[42]$} \\
\hline & $\begin{array}{l}\text { Mixing of OMVs from } \\
\text { multiple Shigella species } \\
\rightarrow \text { MOMVs }\end{array}$ & ND & $\begin{array}{c}\text { Significantly enhanced } \\
\text { cytokine production compared } \\
\text { to SOMVs }\end{array}$ & [38] \\
\hline & $\begin{array}{l}\text { Binary ethylenimine [123] } \\
\text { treatment }\end{array}$ & ND & $\begin{array}{l}\text { Good immunogenic properties } \\
\text { of OMVs }\end{array}$ & {$[124,125]$} \\
\hline & $\begin{array}{c}\text { Nanoencap-sulation of } \\
\text { the OMVs }\end{array}$ & ND & Long-term protection & [39] \\
\hline & $\begin{array}{c}\text { Heat-induced }(\mathrm{HT}) \\
\text { outer-membrane vesicles } \\
\text { development }\end{array}$ & ND & $\begin{array}{l}\text { Higher contents of some } \\
\text { antigenic structures than } \\
\text { classical OMVs }\end{array}$ & {$[40]$} \\
\hline
\end{tabular}

Note: ND. not determined.

One way is to mix OMVs from various Shigella species, which results in multi-serotype outer membrane vesicles (MOMVs). MOMVs have been generated from a mixture of OMVs from S. dysenteriae $1 \Delta$ stx, S. flexneri 2a, 3a and 6, S. boydii type 4 and S. sonnei. In mice, an immunization with MOMVs increased antibody responses, and subsequently, protection against several Shigella serotypes. In addition, mice exhibited a consistent broad-spectrum antibody response, and thus showed protection against all tested serotypes [42]. Similarly, MOMVs produced from several serotypes significantly enhanced cytokine production in rabbits following immunization [50].

Chemical tools can also be utilized to increase the immunological activation potential of OMVs. A treatment of S. flexneri 2a with binary ethylenimine [123] led to the production of OMVs with increased immunological properties. Due to the inactivation of S. flexneri, it can be used as safe OMV-based vaccine $[39,124,125]$.

Coating OMVs with various agents also enhances their immunological potential, stability, and safety. OMVs from S. flexneri were formulated in nano-capsules and applied to mice, which resulted in high and long-lasting immune protection [39]. In another study, Chitosan-TPP coated with an enteric polymer (NP-OMVs) from S. sonnei were highly efficient in triggering persistent immunological responses in mice [126]. 


\section{Conclusions}

OMVs exhibit a broad range of functions that are fundamental for the biology and the ecology of Gram-negative bacteria. These functions include, for example, bacterial cell-cell communication, growth, survival, and pathogenesis as well as the transmission of virulence factors, horizontal gene transfer or the delivery of toxins. Furthermore, due to the assembly of various antigenic structures, OMVs are also key factors for the induction of inflammatory responses in the host, and thus, they are attractive targets for vaccination. Furthermore, due to mixing OMVs from different Shigella serotypes, cross-reactive immunity can be induced. Therefore, the characterization of the biological role of OMVs and an understanding of their bio-generation as well as the identification of local circulating Shigella strains and serotypes is essential to establish them as essential tools to combat bacterial pathogens.

Author Contributions: M.Q. reviewed the literature, prepared the figures and wrote the first draft. J.M. conceptualized, reviewed, edited and wrote the manuscript. M.W. and B.N. organized the tables, edited the figures and the manuscript, and contributed to the review of the literature. All authors have read and agreed to the published version of the manuscript.

Funding: This research was funded by the German Academic Exchange Service (DAAD- 91646398) and the German Research Foundation (DFG_CRC1181-project number C04; DFG—MA 2621/4-1 and DFG-MA 2621/5-1.

Institutional Review Board Statement: Not applicable.

Informed Consent Statement: Not applicable.

Data Availability Statement: Not applicable.

Conflicts of Interest: The authors declare no conflict of interest.

\section{References}

1. Akhondi, H.; Simonsen, K.A. Bacterial Diarrhea. In StatPearls; StatPearls Publishing: Treasure Island, FL, USA, 2021.

2. Khalil, I.A.; Troeger, C.; Blacker, B.F.; Rao, P.C.; Brown, A.; Atherly, D.E.; Brewer, T.G.; Engmann, C.M.; Houpt, E.R.; Kang, G.; et al. Morbidity and mortality due to shigella and enterotoxigenic Escherichia coli diarrhoea: The Global Burden of Disease Study 1990-2016. Lancet Infect. Dis. 2018, 18, 1229-1240. [CrossRef]

3. Kotloff, K.L.; Riddle, M.S.; Platts-Mills, J.A.; Pavlinac, P.; Zaidi, A.K.M. Shigellosis. Lancet 2018, 391, 801-812. [CrossRef]

4. Taneja, N.; Tiewsoh, J.B.A.; Gupta, S.; Mohan, B.; Verma, R.; Shankar, P.; Narayan, C.; Yadav, V.K.; Jayashree, M.; Singh, S. Antimicrobial resistance in Shigella species: Our five years (2015-2019) experience in a tertiary care center in north India. Indian J. Med. Microbiol. 2021, 39, 489-494. [CrossRef]

5. Guglielmino, C.J.D.; Kakkanat, A.; Forde, B.M.; Rubenach, S.; Merone, L.; Stafford, R.; Graham, R.M.A.; Beatson, S.A.; Jennison, A.V. Outbreak of multi-drug-resistant (MDR) Shigella flexneri in northern Australia due to an endemic regional clone acquiring an IncFII plasmid. Eur. J. Clin. Microbiol. Infect Dis. 2021, 40, 279-286. [CrossRef]

6. Mani, S.; Wierzba, T.; Walker, R.I. Status of vaccine research and development for Shigella. Vaccine 2016, 34, 2887-2894. [CrossRef] [PubMed]

7. Chakraborty, S.; Harro, C.; DeNearing, B.; Bream, J.; Bauers, N.; Dally, L.; Flores, J.; Van de Verg, L.; Sack, D.A.; Walker, R. Evaluation of the Safety, Tolerability, and Immunogenicity of an Oral, Inactivated Whole-Cell Shigella flexneri 2a Vaccine in Healthy Adult Subjects. Clin. Vaccine Immunol. 2016, 23, 315-325. [CrossRef] [PubMed]

8. Christensen, H.; Nordentoft, S.; Olsen, J.E. Phylogenetic relationships of Salmonella based on rRNA sequences. Int. J. Syst. Bacteriol. 1998, 48, 605-610. [CrossRef]

9. Sims, G.E.; Kim, S.H. Whole-genome phylogeny of Escherichia coli/Shigella group by feature frequency profiles (FFPs). Proc. Natl. Acad Sci. USA 2011, 108, 8329-8334. [CrossRef] [PubMed]

10. Lecointre, G.; Rachdi, L.; Darlu, P.; Denamur, E. Escherichia coli molecular phylogeny using the incongruence length difference test. Mol. Biol. Evol. 1998, 15, 1685-1695. [CrossRef]

11. Hale, T.L. Genetic basis of virulence in Shigella species. Microbiol. Rev. 1991, 55, 206-224. [CrossRef]

12. Khot, P.D.; Fisher, M.A. Novel approach for differentiating Shigella species and Escherichia coli by matrix-assisted laser desorption ionization-time of flight mass spectrometry. J. Clin. Microbiol. 2013, 51, 3711-3716. [CrossRef]

13. Paauw, A.; Jonker, D.; Roeselers, G.; Heng, J.M.; Mars-Groenendijk, R.H.; Trip, H.; Molhoek, E.M.; Jansen, H.J.; van der Plas, J.; de Jong, A.L.; et al. Rapid and reliable discrimination between Shigella species and Escherichia coli using MALDI-TOF mass spectrometry. Int. J. Med. Microbiol. 2015, 305, 446-452. [CrossRef] [PubMed] 
14. Devanga Ragupathi, N.K.; Muthuirulandi Sethuvel, D.P.; Inbanathan, F.Y.; Veeraraghavan, B. Accurate differentiation of Escherichia coli and Shigella serogroups: Challenges and strategies. New Microbes New Infect. 2018, 21, 58-62. [CrossRef] [PubMed]

15. Liu, J.; Pholwat, S.; Zhang, J.; Taniuchi, M.; Haque, R.; Alam, M.; Ochieng, J.B.; Jones, J.A.; Platts-Mills, J.A.; Tennant, S.M.; et al. Evaluation of Molecular Serotyping Assays for Shigella flexneri Directly on Stool Samples. J. Clin. Microbiol. 2021, 59, e02455-20. [CrossRef] [PubMed]

16. Anderson, M.; Sansonetti, P.J.; Marteyn, B.S. Shigella Diversity and Changing Landscape: Insights for the Twenty-First Century. Front. Cell Infect. Microbiol. 2016, 6, 45. [CrossRef]

17. Mattock, E.; Blocker, A.J. How Do the Virulence Factors of Shigella Work Together to Cause Disease? Front. Cell Infect. Microbiol. 2017, 7, 64. [CrossRef] [PubMed]

18. Levine, M.M.; Kotloff, K.L.; Barry, E.M.; Pasetti, M.F.; Sztein, M.B. Clinical trials of Shigella vaccines: Two steps forward and one step back on a long, hard road. Nat. Rev. Microbiol. 2007, 5, 540-553. [CrossRef]

19. Kotloff, K.L. Shigella infection in children and adults: A formidable foe. Lancet Glob. Health 2017, 5, e1166-e1167. [CrossRef]

20. Connor, T.R.; Barker, C.R.; Baker, K.S.; Weill, F.X.; Talukder, K.A.; Smith, A.M.; Baker, S.; Gouali, M.; Pham Thanh, D.; Jahan Azmi, I.; et al. Species-wide whole genome sequencing reveals historical global spread and recent local persistence in Shigella flexneri. Elife 2015, 4, e07335. [CrossRef]

21. Chang, Z.; Lu, S.; Chen, L.; Jin, Q.; Yang, J. Causative species and serotypes of shigellosis in mainland China: Systematic review and meta-analysis. PLOS ONE 2012, 7, e52515. [CrossRef]

22. von Seidlein, L.; Kim, D.R.; Ali, M.; Lee, H.; Wang, X.; Thiem, V.D.; Canh, D.G.; Chaicumpa, W.; Agtini, M.D.; Hossain, A.; et al. A multicentre study of Shigella diarrhoea in six Asian countries: Disease burden, clinical manifestations, and microbiology. PLoS Med. 2006, 3, e353. [CrossRef] [PubMed]

23. Seol, S.Y.; Kim, Y.T.; Jeong, Y.S.; Oh, J.Y.; Kang, H.Y.; Moon, D.C.; Kim, J.; Lee, Y.C.; Cho, D.T.; Lee, J.C. Molecular characterization of antimicrobial resistance in Shigella sonnei isolates in Korea. J. Med. Microbiol. 2006, 55, 871-877. [CrossRef]

24. Wei, H.L.; Wang, Y.W.; Li, C.C.; Tung, S.K.; Chiou, C.S. Epidemiology and evolution of genotype and antimicrobial resistance of an imported Shigella sonnei clone circulating in central Taiwan. Diagn. Microbiol. Infect. Dis. 2007, 58, 469-475. [CrossRef]

25. Rahman, K.M.; Arifeen, S.E.; Zaman, K.; Rahman, M.; Raqib, R.; Yunus, M.; Begum, N.; Islam, M.S.; Sohel, B.M.; Rahman, M.; et al. Safety, dose, immunogenicity, and transmissibility of an oral live attenuated Shigella flexneri 2a vaccine candidate (SC602) among healthy adults and school children in Matlab, Bangladesh. Vaccine 2011, 29, 1347-1354. [CrossRef] [PubMed]

26. Frenck, R.W., Jr.; Baqar, S.; Alexander, W.; Dickey, M.; McNeal, M.; El-Khorazaty, J.; Baughman, H.; Hoeper, A.; Barnoy, S.; Suvarnapunya, A.E.; et al. A Phase I trial to evaluate the safety and immunogenicity of WRSs2 and WRSs3; two live oral candidate vaccines against Shigella sonnei. Vaccine 2018, 36, 4880-4889. [CrossRef] [PubMed]

27. Kweon, M.N. Shigellosis: The current status of vaccine development. Curr. Opin. Infect. Dis. 2008, 21, 313-318. [CrossRef] [PubMed]

28. Furuyama, N.; Sircili, M.P. Outer Membrane Vesicles (OMVs) Produced by Gram-Negative Bacteria: Structure, Functions, Biogenesis, and Vaccine Application. Biomed. Res. Int. 2021, 2021, 1490732. [CrossRef] [PubMed]

29. Schwechheimer, C.; Kuehn, M.J. Outer-membrane vesicles from Gram-negative bacteria: Biogenesis and functions. Nat. Rev. Microbiol. 2015, 13, 605-619. [CrossRef]

30. Bittel, M.; Reichert, P.; Sarfati, I.; Dressel, A.; Leikam, S.; Uderhardt, S.; Stolzer, I.; Phu, T.A.; Ng, M.; Vu, N.K.; et al. Visualizing transfer of microbial biomolecules by outer membrane vesicles in microbe-host-communication in vivo. J. Extracell. Vesicles 2021, 10, e12159. [CrossRef]

31. Balhuizen, M.D.; Veldhuizen, E.J.A.; Haagsman, H.P. Outer Membrane Vesicle Induction and Isolation for Vaccine Development. Front. Microbiol. 2021, 12, 629090. [CrossRef]

32. Cai, W.; Kesavan, D.K.; Wan, J.; Abdelaziz, M.H.; Su, Z.; Xu, H. Bacterial outer membrane vesicles, a potential vaccine candidate in interactions with host cells based. Diagn. Pathol. 2018, 13, 95. [CrossRef] [PubMed]

33. Lee, J.; Yoon, Y.J.; Kim, J.H.; Dinh, N.T.H.; Go, G.; Tae, S.; Park, K.S.; Park, H.T.; Lee, C.; Roh, T.Y.; et al. Outer Membrane Vesicles Derived From Escherichia coli Regulate Neutrophil Migration by Induction of Endothelial IL-8. Front. Microbiol. 2018, 9, 2268. [CrossRef] [PubMed]

34. Zanella, I.; Konig, E.; Tomasi, M.; Gagliardi, A.; Frattini, L.; Fantappie, L.; Irene, C.; Zerbini, F.; Caproni, E.; Isaac, S.J.; et al Proteome-minimized outer membrane vesicles from Escherichia coli as a generalized vaccine platform. J. Extracell. Vesicles 2021, 10, e12066. [CrossRef] [PubMed]

35. Adriani, R.; Mousavi Gargari, S.L.; Nazarian, S.; Sarvary, S.; Noroozi, N. Immunogenicity of Vibrio cholerae outer membrane vesicles secreted at various environmental conditions. Vaccine 2018, 36, 322-330. [CrossRef]

36. Gerritzen, M.J.H.; Martens, D.E.; Uittenbogaard, J.P.; Wijffels, R.H.; Stork, M. Sulfate depletion triggers overproduction of phospholipids and the release of outer membrane vesicles by Neisseria meningitidis. Sci. Rep. 2019, 9, 4716. [CrossRef]

37. Gerritzen, M.J.H.; Salverda, M.L.M.; Martens, D.E.; Wijffels, R.H.; Stork, M. Spontaneously released Neisseria meningitidis outer membrane vesicles as vaccine platform: Production and purification. Vaccine 2019, 37, 6978-6986. [CrossRef]

38. Mitra, S.; Sinha, R.; Mitobe, J.; Koley, H. Development of a cost-effective vaccine candidate with outer membrane vesicles of a tolA-disrupted Shigella boydii strain. Vaccine 2016, 34, 1839-1846. [CrossRef] 
39. Camacho, A.I.; Irache, J.M.; de Souza, J.; Sanchez-Gomez, S.; Gamazo, C. Nanoparticle-based vaccine for mucosal protection against Shigella flexneri in mice. Vaccine 2013, 31, 3288-3294. [CrossRef]

40. Pastor, Y.; Camacho, A.; Gil, A.G.; Ramos, R.; Cerain, A.L.; Penuelas, I.; Irache, J.M.; Gamazo, C. Effective protection of mice against Shigella flexneri with a new self-adjuvant multicomponent vaccine. J. Med. Microbiol. 2017, 66, 946-958. [CrossRef]

41. Mitra, S.; Barman, S.; Nag, D.; Sinha, R.; Saha, D.R.; Koley, H. Outer membrane vesicles of Shigella boydii type 4 induce passive immunity in neonatal mice. FEMS Immunol. Med. Microbiol. 2012, 66, 240-250. [CrossRef]

42. Mitra, S.; Chakrabarti, M.K.; Koley, H. Multi-serotype outer membrane vesicles of Shigellae confer passive protection to the neonatal mice against shigellosis. Vaccine 2013, 31, 3163-3173. [CrossRef] [PubMed]

43. Nag, D.; Sinha, R.; Mitra, S.; Barman, S.; Takeda, Y.; Shinoda, S.; Chakrabarti, M.K.; Koley, H. Heat killed multi-serotype Shigella immunogens induced humoral immunity and protection against heterologous challenge in rabbit model. Immunobiology 2015, 220, 1275-1283. [CrossRef]

44. Camacho, A.I.; de Souza, J.; Sanchez-Gomez, S.; Pardo-Ros, M.; Irache, J.M.; Gamazo, C. Mucosal immunization with Shigella flexneri outer membrane vesicles induced protection in mice. Vaccine 2011, 29, 8222-8229. [CrossRef] [PubMed]

45. Pore, D.; Mahata, N.; Pal, A.; Chakrabarti, M.K. Outer membrane protein A (OmpA) of Shigella flexneri 2a, induces protective immune response in a mouse model. PLoS ONE 2011, 6, e22663. [CrossRef] [PubMed]

46. Pore, D.; Chakrabarti, M.K. Outer membrane protein A (OmpA) from Shigella flexneri 2a: A promising subunit vaccine candidate Vaccine 2013, 31, 3644-3650. [CrossRef] [PubMed]

47. Wolf, M.; Schimpl, A.; Hunig, T. Control of T cell hyperactivation in IL-2-deficient mice by CD4(+)CD25(-) and CD4(+)CD25(+) T cells: Evidence for two distinct regulatory mechanisms. Eur. J. Immunol. 2001, 31, 1637-1645. [CrossRef]

48. Jarzab, A.; Witkowska, D.; Ziomek, E.; Dabrowska, A.; Szewczuk, Z.; Gamian, A. Shigella flexneri 3a outer membrane protein C epitope is recognized by human umbilical cord sera and associated with protective activity. PLoS ONE 2013, 8, e70539. [CrossRef] [PubMed]

49. Berlanda Scorza, F.; Colucci, A.M.; Maggiore, L.; Sanzone, S.; Rossi, O.; Ferlenghi, I.; Pesce, I.; Caboni, M.; Norais, N.; Di Cioccio, V.; et al. High yield production process for Shigella outer membrane particles. PLoS ONE 2012, 7, e35616. [CrossRef]

50. Gerke, C.; Colucci, A.M.; Giannelli, C.; Sanzone, S.; Vitali, C.G.; Sollai, L.; Rossi, O.; Martin, L.B.; Auerbach, J.; Di Cioccio, V.; et al. Production of a Shigella sonnei Vaccine Based on Generalized Modules for Membrane Antigens (GMMA), 1790GAHB. PLoS ONE 2015, 10, e0134478. [CrossRef]

51. Kim, J.O.; Rho, S.; Kim, S.H.; Kim, H.; Song, H.J.; Kim, E.J.; Kim, R.Y.; Kim, E.H.; Sinha, A.; Dey, A.; et al. Shigella outer membrane protein PSSP-1 is broadly protective against Shigella infection. Clin. Vaccine Immunol. 2015, 22, 381-388. [CrossRef]

52. Pore, D.; Chowdhury, P.; Mahata, N.; Pal, A.; Yamasaki, S.; Mahalanabis, D.; Chakrabarti, M.K. Purification and characterization of an immunogenic outer membrane protein of Shigella flexneri 2a. Vaccine 2009, 27, 5855-5864. [CrossRef]

53. Pore, D.; Mahata, N.; Pal, A.; Chakrabarti, M.K. 34 kDa MOMP of Shigella flexneri promotes TLR2 mediated macrophage activation with the engagement of NF-kappaB and p38 MAP kinase signaling. Mol. Immunol. 2010, 47, 1739-1746. [CrossRef] [PubMed]

54. Mukhopadhaya, A.; Mahalanabis, D.; Chakrabarti, M.K. Role of Shigella flexneri 2a 34 kDa outer membrane protein in induction of protective immune response. Vaccine 2006, 24, 6028-6036. [CrossRef]

55. Bagchi, A.K.; Sinha, A.K. Role of $57 \mathrm{kDa}$ major antigenic component of Shigella dysenteriae outer membrane proteins in induction of major histocompatibility complex II-restricted T-cell response. Arch. Med. Res. 2004, 35, 427-434. [CrossRef]

56. Bhowmick, R.; Pore, D.; Chakrabarti, M.K. Outer membrane protein A (OmpA) of Shigella flexneri 2a induces TLR2-mediated activation of B cells: Involvement of protein tyrosine kinase, ERK and NF-kappaB. PLoS ONE 2014, 9, e109107. [CrossRef]

57. Sharma, D.; Yagnik, B.; Baksi, R.; Desai, N.; Padh, H.; Desai, P. Shigellosis murine model established by intraperitoneal and intranasal route of administration: A comparative comprehension overview. Microbes Infect. 2017, 19, 47-54. [CrossRef] [PubMed]

58. Yagnik, B.; Sharma, D.; Padh, H.; Desai, P. Oral immunization with LacVax(R) OmpA induces protective immune response against Shigella flexneri 2a ATCC 12022 in a murine model. Vaccine 2019, 37, 3097-3105. [CrossRef] [PubMed]

59. Padh, H.; Yagnik, B.; Sharma, D.; Desai, P. EpiMix Based Novel Vaccine Candidate for Shigella: Evidence of Prophylactic Immunity in Balb/c Mice. Int. J. Pept. Res. Ther. 2021, 27, 1095-1110. [CrossRef]

60. Paciello, I.; Silipo, A.; Lembo-Fazio, L.; Curcuru, L.; Zumsteg, A.; Noel, G.; Ciancarella, V.; Sturiale, L.; Molinaro, A.; Bernardini, M.L. Intracellular Shigella remodels its LPS to dampen the innate immune recognition and evade inflammasome activation. Proc. Natl. Acad. Sci. USA 2013, 110, E4345-E4354. [CrossRef]

61. Cohen, D.; Meron-Sudai, S.; Bialik, A.; Asato, V.; Goren, S.; Ariel-Cohen, O.; Reizis, A.; Hochberg, A.; Ashkenazi, S. Serum IgG antibodies to Shigella lipopolysaccharide antigens-A correlate of protection against shigellosis. Hum. Vaccin Immunother. 2019, 15, 1401-1408. [CrossRef]

62. Barel, L.A.; Mulard, L.A. Classical and novel strategies to develop a Shigella glycoconjugate vaccine: From concept to efficacy in human. Hum. Vaccin Immunother. 2019, 15, 1338-1356. [CrossRef]

63. Silipo, A.; Molinaro, A. The diversity of the core oligosaccharide in lipopolysaccharides. Subcell. Biochem. 2010, 53, 69-99. [CrossRef]

64. Akesson, K.; Tompa, A.; Ryden, A.; Faresjo, M. Low expression of CD39(+) /CD45RA(+) on regulatory T cells (Treg) cells in type 1 diabetic children in contrast to high expression of CD101(+) /CD129(+) on Treg cells in children with coeliac disease. Clin. Exp. Immunol. 2015, 180, 70-82. [CrossRef] 
65. Pore, D.; Mahata, N.; Chakrabarti, M.K. Outer membrane protein A (OmpA) of Shigella flexneri 2a links innate and adaptive immunity in a TLR2-dependent manner and involvement of IL-12 and nitric oxide. J. Biol. Chem. 2012, 287, 12589-12601. [CrossRef]

66. Allaoui, A.; Sansonetti, P.J.; Parsot, C. MxiD, an outer membrane protein necessary for the secretion of the Shigella flexneri lpa invasins. Mol. Microbiol. 1993, 7, 59-68. [CrossRef]

67. Schuch, R.; Maurelli, A.T. MxiM and MxiJ, base elements of the Mxi-Spa type III secretion system of Shigella, interact with and stabilize the MxiD secretin in the cell envelope. J. Bacteriol. 2001, 183, 6991-6998. [CrossRef] [PubMed]

68. Schroeder, G.N.; Hilbi, H. Molecular pathogenesis of Shigella spp.: Controlling host cell signaling, invasion, and death by type III secretion. Clin. Microbiol. Rev. 2008, 21, 134-156. [CrossRef]

69. Bernardini, M.L.; Sanna, M.G.; Fontaine, A.; Sansonetti, P.J. OmpC is involved in invasion of epithelial cells by Shigella flexneri. Infect. Immun. 1993, 61, 3625-3635. [CrossRef] [PubMed]

70. Allaoui, A.; Sansonetti, P.J.; Parsot, C. MxiJ, a lipoprotein involved in secretion of Shigella Ipa invasins, is homologous to YscJ, a secretion factor of the Yersinia Yop proteins. J. Bacteriol. 1992, 174, 7661-7669. [CrossRef] [PubMed]

71. Ambrosi, C.; Pompili, M.; Scribano, D.; Zagaglia, C.; Ripa, S.; Nicoletti, M. Outer membrane protein A (OmpA): A new player in shigella flexneri protrusion formation and inter-cellular spreading. PLoS ONE 2012, 7, e49625. [CrossRef]

72. Tiku, V.; Kofoed, E.M.; Yan, D.; Kang, J.; Xu, M.; Reichelt, M.; Dikic, I.; Tan, M.W. Outer membrane vesicles containing OmpA induce mitochondrial fragmentation to promote pathogenesis of Acinetobacter baumannii. Sci. Rep. 2021, 11, 618. [CrossRef]

73. Murphy, E.R.; Rossmanith, J.; Sieg, J.; Fris, M.E.; Hussein, H.; Kouse, A.B.; Gross, K.; Zeng, C.; Hines, J.V.; Narberhaus, F.; et al . Regulation of OmpA Translation and Shigella dysenteriae Virulence by an RNA Thermometer. Infect. Immun. 2020, 88, e00871-19. [CrossRef]

74. Confer, A.W.; Ayalew, S. The OmpA family of proteins: Roles in bacterial pathogenesis and immunity. Vet. Microbiol. 2013, 163, 207-222. [CrossRef] [PubMed]

75. Smith, S.G.; Mahon, V.; Lambert, M.A.; Fagan, R.P. A molecular Swiss army knife: OmpA structure, function and expression FEMS Microbiol. Lett. 2007, 273, 1-11. [CrossRef]

76. Brotcke Zumsteg, A.; Goosmann, C.; Brinkmann, V.; Morona, R.; Zychlinsky, A. IcsA is a Shigella flexneri adhesin regulated by the type III secretion system and required for pathogenesis. Cell Host Microbe. 2014, 15, 435-445. [CrossRef] [PubMed]

77. Robbins, J.R.; Monack, D.; McCallum, S.J.; Vegas, A.; Pham, E.; Goldberg, M.B.; Theriot, J.A. The making of a gradient: IcsA (VirG) polarity in Shigella flexneri. Mol. Microbiol. 2001, 41, 861-872. [CrossRef] [PubMed]

78. Goldberg, M.B.; Theriot, J.A. Shigella flexneri surface protein IcsA is sufficient to direct actin-based motility. Proc. Natl. Acad. Sci. USA 1995, 92, 6572-6576. [CrossRef]

79. d'Hauteville, H.; Sansonetti, P.J. Phosphorylation of IcsA by cAMP-dependent protein kinase and its effect on intracellular spread of Shigella flexneri. Mol. Microbiol. 1992, 6, 833-841. [CrossRef]

80. Koseoglu, V.K.; Hall, C.P.; Rodriguez-Lopez, E.M.; Agaisse, H. The Autotransporter IcsA Promotes Shigella flexneri Biofilm Formation in the Presence of Bile Salts. Infect. Immun. 2019, 87, e00861-18. [CrossRef]

81. Egile, C.; d'Hauteville, H.; Parsot, C.; Sansonetti, P.J. SopA, the outer membrane protease responsible for polar localization of IcsA in Shigella flexneri. Mol. Microbiol. 1997, 23, 1063-1073. [CrossRef]

82. Raffatellu, M.; Wilson, R.P.; Chessa, D.; Andrews-Polymenis, H.; Tran, Q.T.; Lawhon, S.; Khare, S.; Adams, L.G.; Baumler, A.J. SipA, SopA, SopB, SopD, and SopE2 contribute to Salmonella enterica serotype typhimurium invasion of epithelial cells. Infect. Immun. 2005, 73, 146-154. [CrossRef] [PubMed]

83. Zhang, S.; Santos, R.L.; Tsolis, R.M.; Stender, S.; Hardt, W.D.; Baumler, A.J.; Adams, L.G. The Salmonella enterica serotype typhimurium effector proteins SipA, SopA, SopB, SopD, and SopE2 act in concert to induce diarrhea in calves. Infect. Immun. 2002, 70, 3843-3855. [CrossRef]

84. Jain, S.; Goldberg, M.B. Requirement for YaeT in the outer membrane assembly of autotransporter proteins. J. Bacteriol. 2007, 189, 5393-5398. [CrossRef] [PubMed]

85. Doerrler, W.T.; Raetz, C.R. Loss of outer membrane proteins without inhibition of lipid export in an Escherichia coli YaeT mutant. J. Biol. Chem. 2005, 280, 27679-27687. [CrossRef]

86. Smith, D.L.; James, C.E.; Sergeant, M.J.; Yaxian, Y.; Saunders, J.R.; McCarthy, A.J.; Allison, H.E. Short-tailed stx phages exploit the conserved YaeT protein to disseminate Shiga toxin genes among enterobacteria. J. Bacteriol. 2007, 189, 7223-7233. [CrossRef]

87. Werner, J.; Misra, R. YaeT (Omp85) affects the assembly of lipid-dependent and lipid-independent outer membrane proteins of Escherichia coli. Mol. Microbiol. 2005, 57, 1450-1459. [CrossRef]

88. Shere, K.D.; Sallustio, S.; Manessis, A.; D'Aversa, T.G.; Goldberg, M.B. Disruption of IcsP, the major Shigella protease that cleaves IcsA, accelerates actin-based motility. Mol. Microbiol. 1997, 25, 451-462. [CrossRef]

89. Steinhauer, J.; Agha, R.; Pham, T.; Varga, A.W.; Goldberg, M.B. The unipolar Shigella surface protein IcsA is targeted directly to the bacterial old pole: IcsP cleavage of IcsA occurs over the entire bacterial surface. Mol. Microbiol. 1999, 32, 367-377. [CrossRef] [PubMed]

90. Wing, H.J.; Goldman, S.R.; Ally, S.; Goldberg, M.B. Modulation of an outer membrane protease contributes to the virulence defect of Shigella flexneri strains carrying a mutation in the virK locus. Infect. Immun. 2005, 73, 1217-1220. [CrossRef] 
91. Hensley, C.T.; Kamneva, O.K.; Levy, K.M.; Labahn, S.K.; Africa, L.A.; Wing, H.J. Two promoters and two translation start sites control the expression of the Shigella flexneri outer membrane protease IcsP. Arch. Microbiol. 2011, 193, 263-274. [CrossRef] [PubMed]

92. Africa, L.A.; Murphy, E.R.; Egan, N.R.; Wigley, A.F.; Wing, H.J. The iron-responsive Fur/RyhB regulatory cascade modulates the Shigella outer membrane protease IcsP. Infect. Immun. 2011, 79, 4543-4549. [CrossRef]

93. Rossi, R.M.; Yum, L.; Agaisse, H.; Payne, S.M. Cardiolipin Synthesis and Outer Membrane Localization Are Required for Shigella flexneri Virulence. MBio 2017, 8, e01199-17. [CrossRef]

94. Douglass, M.V.; Cleon, F.; Trent, M.S. Cardiolipin aids in lipopolysaccharide transport to the gram-negative outer membrane. Proc. Natl. Acad. Sci. USA 2021, 118, e2018329118. [CrossRef]

95. Wang, X.; Jiang, F.; Zheng, J.; Chen, L.; Dong, J.; Sun, L.; Zhu, Y.; Liu, B.; Yang, J.; Yang, G.; et al. The outer membrane phospholipase A is essential for membrane integrity and type III secretion in Shigella flexneri. Open Biol. 2016, 6, 160073. [CrossRef] [PubMed]

96. Wu, E.L.; Fleming, P.J.; Yeom, M.S.; Widmalm, G.; Klauda, J.B.; Fleming, K.G.; Im, W.E. coli outer membrane and interactions with OmpLA. Biophys. J. 2014, 106, 2493-2502. [CrossRef] [PubMed]

97. Schuch, R.; Maurelli, A.T. The mxi-Spa type III secretory pathway of Shigella flexneri requires an outer membrane lipoprotein, MxiM, for invasin translocation. Infect. Immun. 1999, 67, 1982-1991. [CrossRef] [PubMed]

98. Ojima, Y.; Sawabe, T.; Konami, K.; Azuma, M. Construction of hypervesiculation Escherichia coli strains and application for secretory protein production. Biotechnol. Bioeng. 2020, 117, 701-709. [CrossRef]

99. Micoli, F.; Alfini, R.; Di Benedetto, R.; Necchi, F.; Schiavo, F.; Mancini, F.; Carducci, M.; Palmieri, E.; Balocchi, C.; Gasperini, G.; et al GMMA Is a Versatile Platform to Design Effective Multivalent Combination Vaccines. Vaccines 2020, 8, 540. [CrossRef]

100. Chen, L.; Valentine, J.L.; Huang, C.J.; Endicott, C.E.; Moeller, T.D.; Rasmussen, J.A.; Fletcher, J.R.; Boll, J.M.; Rosenthal, J.A.; Dobruchowska, J.; et al. Outer membrane vesicles displaying engineered glycotopes elicit protective antibodies. Proc. Natl. Acad. Sci. USA 2016, 113, E3609-E3618. [CrossRef]

101. Ferrari, G.; Garaguso, I.; Adu-Bobie, J.; Doro, F.; Taddei, A.R.; Biolchi, A.; Brunelli, B.; Giuliani, M.M.; Pizza, M.; Norais, N.; et al Outer membrane vesicles from group B Neisseria meningitidis delta gna33 mutant: Proteomic and immunological comparison with detergent-derived outer membrane vesicles. Proteomics 2006, 6, 1856-1866. [CrossRef] [PubMed]

102. Elhenawy, W.; Bording-Jorgensen, M.; Valguarnera, E.; Haurat, M.F.; Wine, E.; Feldman, M.F. LPS Remodeling Triggers Formation of Outer Membrane Vesicles in Salmonella. MBio 2016, 7, e00940-16. [CrossRef] [PubMed]

103. Gerritzen, M.J.H.; Maas, R.H.W.; van den Ijssel, J.; van Keulen, L.; Martens, D.E.; Wijffels, R.H.; Stork, M. High dissolved oxygen tension triggers outer membrane vesicle formation by Neisseria meningitidis. Microb. Cell Fact. 2018, 17, 157. [CrossRef] [PubMed]

104. Baumgarten, T.; Sperling, S.; Seifert, J.; von Bergen, M.; Steiniger, F.; Wick, L.Y.; Heipieper, H.J. Membrane vesicle formation as a multiple-stress response mechanism enhances Pseudomonas putida DOT-T1E cell surface hydrophobicity and biofilm formation. Appl. Environ. Microbiol. 2012, 78, 6217-6224. [CrossRef]

105. Eberlein, C.; Baumgarten, T.; Starke, S.; Heipieper, H.J. Immediate response mechanisms of Gram-negative solvent-tolerant bacteria to cope with environmental stress: Cis-trans isomerization of unsaturated fatty acids and outer membrane vesicle secretion. Appl. Microbiol. Biotechnol. 2018, 102, 2583-2593. [CrossRef]

106. Acevedo, R.; Fernandez, S.; Zayas, C.; Acosta, A.; Sarmiento, M.E.; Ferro, V.A.; Rosenqvist, E.; Campa, C.; Cardoso, D.; Garcia, L.; et al. Bacterial outer membrane vesicles and vaccine applications. Front. Immunol. 2014, 5, 121. [CrossRef] [PubMed]

107. Van der Pol, L.; Stork, M.; van der Ley, P. Outer membrane vesicles as platform vaccine technology. Biotechnol. J. 2015, 10, 1689-1706. [CrossRef] [PubMed]

108. Schertzer, J.W.; Whiteley, M. A bilayer-couple model of bacterial outer membrane vesicle biogenesis. MBio 2012, 3, e00297-11. [CrossRef]

109. Kuerban, K.; Gao, X.; Zhang, H.; Liu, J.; Dong, M.; Wu, L.; Ye, R.; Feng, M.; Ye, L. Doxorubicin-loaded bacterial outer-membrane vesicles exert enhanced anti-tumor efficacy in non-small-cell lung cancer. Acta Pharm. Sin. B 2020, 10, 1534-1548. [CrossRef]

110. Chan, K.W.; Shone, C.; Hesp, J.R. Antibiotics and iron-limiting conditions and their effect on the production and composition of outer membrane vesicles secreted from clinical isolates of extraintestinal pathogenic E. coli. Proteom. Clin. Appl. 2017, 11, 1600091. [CrossRef]

111. Manning, A.J.; Kuehn, M.J. Contribution of bacterial outer membrane vesicles to innate bacterial defense. BMC Microbiol. 2011, 11, 258. [CrossRef]

112. Roberts, R.; Moreno, G.; Bottero, D.; Gaillard, M.E.; Fingermann, M.; Graieb, A.; Rumbo, M.; Hozbor, D. Outer membrane vesicles as acellular vaccine against pertussis. Vaccine 2008, 26, 4639-4646. [CrossRef]

113. Asensio, C.J.; Gaillard, M.E.; Moreno, G.; Bottero, D.; Zurita, E.; Rumbo, M.; van der Ley, P.; van der Ark, A.; Hozbor, D. Outer membrane vesicles obtained from Bordetella pertussis Tohama expressing the lipid A deacylase PagL as a novel acellular vaccine candidate. Vaccine 2011, 29, 1649-1656. [CrossRef]

114. Bottero, D.; Zurita, M.E.; Gaillard, M.E.; Bartel, E.; Vercellini, C.; Hozbor, D. Membrane Vesicles Derived from Bordetella bronchiseptica: Active Constituent of a New Vaccine against Infections Caused by This Pathogen. Appl. Environ. Microbiol. 2018, 84, e01877-17. [CrossRef] [PubMed] 
115. Schwechheimer, C.; Kuehn, M.J. Synthetic effect between envelope stress and lack of outer membrane vesicle production in Escherichia coli. J. Bacteriol. 2013, 195, 4161-4173. [CrossRef] [PubMed]

116. Takaki, K.; Tahara, Y.O.; Nakamichi, N.; Hasegawa, Y.; Shintani, M.; Ohkuma, M.; Miyata, M.; Futamata, H.; Tashiro, Y. Multilamellar and Multivesicular Outer Membrane Vesicles Produced by a Buttiauxella agrestis tolB Mutant. Appl. Environ. Microbiol. 2020, 86, e01131-20. [CrossRef] [PubMed]

117. Perez-Cruz, C.; Canas, M.A.; Gimenez, R.; Badia, J.; Mercade, E.; Baldoma, L.; Aguilera, L. Membrane Vesicles Released by a hypervesiculating Escherichia coli Nissle 1917 tolR Mutant Are Highly Heterogeneous and Show Reduced Capacity for Epithelial Cell Interaction and Entry. PLoS ONE 2016, 11, e0169186. [CrossRef]

118. Michel, L.V.; Gallardo, L.; Konovalova, A.; Bauer, M.; Jackson, N.; Zavorin, M.; McNamara, C.; Pierce, J.; Cheng, S.; Snyder, E.; et al. Ampicillin triggers the release of Pal in toxic vesicles from Escherichia coli. Int. J. Antimicrob. Agents 2020, 56, 106163. [CrossRef]

119. Yun, S.H.; Park, E.C.; Lee, S.Y.; Lee, H.; Choi, C.W.; Yi, Y.S.; Ro, H.J.; Lee, J.C.; Jun, S.; Kim, H.Y.; et al. Antibiotic treatment modulates protein components of cytotoxic outer membrane vesicles of multidrug-resistant clinical strain, Acinetobacter baumannii DU202. Clin. Proteom. 2018, 15, 28. [CrossRef]

120. Kesavan, D.; Vasudevan, A.; Wu, L.; Chen, J.; Su, Z.; Wang, S.; Xu, H. Integrative analysis of outer membrane vesicles proteomics and whole-cell transcriptome analysis of eravacycline induced Acinetobacter baumannii strains. BMC Microbiol. 2020, $20,31$. [CrossRef]

121. Pastor, Y.; Camacho, A.I.; Zuniga-Ripa, A.; Merchan, A.; Rosas, P.; Irache, J.M.; Gamazo, C. Towards a subunit vaccine from a Shigella flexneri DeltatolR mutant. Vaccine 2018, 36, 7509-7519. [CrossRef]

122. Sidik, S.; Kottwitz, H.; Benjamin, J.; Ryu, J.; Jarrar, A.; Garduno, R.; Rohde, J.R. A Shigella flexneri virulence plasmid encoded factor controls production of outer membrane vesicles. G3 2014, 4, 2493-2503. [CrossRef] [PubMed]

123. Fernandez, I.; Zeiser, R.; Karsunky, H.; Kambham, N.; Beilhack, A.; Soderstrom, K.; Negrin, R.S.; Engleman, E. CD101 surface expression discriminates potency among murine FoxP3+ regulatory T cells. J. Immunol. 2007, 179, 2808-2814. [CrossRef] [PubMed]

124. Camacho, A.I.; Irache, J.M.; Gamazo, C. Recent progress towards development of a Shigella vaccine. Expert Rev. Vaccines 2013, 12, 43-55. [CrossRef] [PubMed]

125. Camacho, A.I.; Souza-Reboucas, J.; Irache, J.M.; Gamazo, C. Towards a non-living vaccine against Shigella flexneri: From the inactivation procedure to protection studies. Methods 2013, 60, 264-268. [CrossRef] [PubMed]

126. Mohammed, M.A.; Syeda, J.T.M.; Wasan, K.M.; Wasan, E.K. An Overview of Chitosan Nanoparticles and Its Application in Non-Parenteral Drug Delivery. Pharmaceutics 2017, 9, 53. [CrossRef] 